\title{
TERRESTRIAL MOLLUSCS AND PALEOECOLOGY OF PREHISTORIC MAN LIVING FLOOR IN THE MIDDLE NISTRU BASIN
}

\author{
Prepelița Afanasie, Trifan Tudor \\ State Tiraspol University, Chisinau, Republic of Moldova, \\ e-mail:prepelitatanas@gmail.com
}

https://doi.org/10.53937/9789975315975.57

The living floors from Paleolithic settlements with traces of human activity, such as silex and bone tools, hunted animal remains, fireplaces, etc. is a valuable testimony to prehistoric man way of life and environmental conditions. Of particular importance in this respect are the cultural layers from the pluristratified settlement Cosăuți, located in the middle section of the Nistru river valley, Soroca district. As result of detailed and complex researches undertaken within the settlement, twenty one cultural levels have been identified and described which, from a geochemical point of view, range from about 13000 to 20000 years BP. The settlement is a reference one for Gravettian and the Epigravettian culture within Central Europe [2].

The sediments that have preserved traces of dwelling structures, keep vestiges of various organisms that lived during the formation of cultural level. These are terrestrial gastropods, which represent our topic of research and have been analyzed on the basis of approved methodological principles [3]. A sample of terrestrial gastropod shells recovered from the rocks that comprise the III living floor from the Cosăuți settlement (over 680 copies) proved to be sufficiently representative from paleoecological point of view. Basing on radiocarbon dating (C14), the III living floor to which we refer has $18.030 \pm 150 \mathrm{BP}(\mathrm{GrN}-21359)$. This date corresponds to Würm (= Valdai) glaciation phase of the European continent and also specifies an important paleogeographical event - the most pronounced climate change in the Quaternary history (20-18 thousand BP) [4]. 
Table 1. The number and ecology of terrestrial gastropods

\begin{tabular}{|l|l|l|l|}
\hline No. & Name of species & Number & $\begin{array}{l}\text { Types of habitat /Ecological } \\
\text { groups (Puissegur, 1976) }\end{array}$ \\
\hline 1. & Helicopsis striata (Mull.) & 2 & Steppe \\
\hline 2 & Vallonia tenuilabris (Al.Br.) & 103 & Open habitats \\
\hline 3 & Pupilla muscorum (L.) & 248 & \multirow{2}{*}{ Mesophilic } \\
\hline 4 & Trihia hispida (L.) & 15 & \\
\hline 5 & Succinea oblonga (Drap.) & 328 & \\
\hline
\end{tabular}

The identified fauna is represented by 5 species (Table 1). They are all currently met in the most recent fauna of the region, except of Vallonia tenuilabris - a North-Asian element, zoogeographically attributed to the fauna of Taiga [5]. The specimens, according to the habitat, are assigned to three ecological groups. So, Helicopsis striata species are part of the Steppe fauna and currently inhabit dry biotopes with herbaceous vegetation, rocky places and grooves. As for Vallonia tenuilabris and Pupilla muscorum, they are mainly found on open fields and are quite flexible to temperature and humidity. The species Trihia hispida and Succinea oblonga are considered mesophilic elements, quite flexible to temperature and type of vegetation, and can be consequently assigned to euribiont species [3]. Some features of the analyzed fauna are distinguished:

- the largest share of the reminiscences of individuals belongs to the species Succinea oblonga - about 48\%, followed by Pupilla muscorum with about $36 \%$.

- all constituent elements are met or can live in open biotopes, and regarding the humidity, unlike Helicopsis striata, they all prefer wet places.

- by composition, fauna has no analogy in the contemporary one, since the elements which were met together, currently have a distinct area of distribution.

Fauna with Succinea is frequently reported in loess deposits in Central Europe. It is distinguished as a poor fauna by the number of species, 
having elements of the genus Pupilla, and rarely Trichia hispida, Vallonia tenuilabris, Helicopsis striata. This type of fauna is an indicator of a climate improvement phase with a tendency towards heating and increasing the degree of humidity, against the background of an overall cold climate. It also means a decrease in the processes of accumulation of loess [1].

In conclusion, we note that the mixed nature of the terrestrial gastropods reveals different environmental circumstances comparing to the current ones. Based on the paleoecology of the studied fauna it can be concluded that prehistoric people, the creators of the III cultural complex from Cosăuți, lived 18000 years ago in cold climate and a landscape dominated by a loess steppe or tundra-steppe.

\section{BIBLIOGRAPHY:}

1. Alexandrowicz,W.P., Malacological sequence of Weichselian (MIS 5-2) loess series from a profile in Grodzisko Dolne (southern Poland) and its palaeogeographic significance, Quaternary International 319, 2014, p.109-119.

2. Haesaerts P., Borziac I., Chirica V. Cadre stratigraphique et chronologique du Gravettien en Europe centrale. In Paleo. Revue d'archéologie préhistorique, 19, 2007, p. 31-51.

3. Puisségur, J.J.,. Mollusques continentaux quaternaries de Bourgogne. Significations

stratigraphiques et climatiques. In: Mémoires géologiques de I' Université de Dijon, vol. 3,1976.

4. Маркова А.К., Т. ван Кольфсхотен, Ш. Бохнкке, П.А. Косинцев, И. Мол,А.Ю.Пузаченко, А.Н.Симакова, Н.Г.Смирнов, А.Верпоорте, И.Б. Головачев.. Эволюция экосистем Европы при переходе от плейстоцена к голоцену (24 - 8 тыс. А.Н.). ИзАательство КМК, 2008.

5. ^ихарев И., Раммельмейер Е. Наземные мол^юски фауны СССР. Москва, 1952. 